\title{
A Viagem de Anne Seymour Damer a Lisboa [1790-1791] e a Representação de Portugal Pitoresco, Católico e Sentimentalista como Espaço de Convalescença e Aprendizagem em Belmour [1801] e na Correspondência da Escultora
}

Rogério Miguel Puga

(FCSH-NOVA/CETAPS)

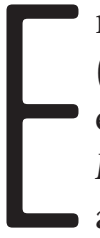

m Julho de 1801, a escultora inglesa Anne Seymour Damer (née Conway; 1749-1828), ${ }^{1}$ que visitara Lisboa entre 1790 e 1791, publicou, anonimamente, o seu único romance Belmour (3 volumes), que tem como um dos espaços da acção a capital portuguesa, pois o protagonista que dá nome à narrativa viaja até ao Sul da Europa, em busca da sua amada, Emily Melville. O presente artigo analisa a representação dos espaços lusos, quer na correspondência da autora, quer no referido romance através de temáticas como a religião, a paisagem etnográfica e histórica. Tendo Percy Noble (1908) e, mais recentemente, Jonathan Gross ("Introduction" 2011; A Life, 2014) ${ }^{2}$ biografado a vida da autora com base nos seus notebooks ${ }^{3}$ (correspondência com a amiga Mary Berry),

1. Sobre a vida e obra de Damer, veja-se o estudo recente de Gross, The Life of Anne Damer (2014), que indica como ano de nascimento da artista-romancista 1748. (1)

2. Ao descrever a viagem de Damer, Gross (2014) segue, de perto, o estudo de Percy Noble (1908); vejam-se, por exemplo, as páginas 126-127 de Noble e a página 156 de Gross.

3. Anne queimou os apontamentos pessoais da viagem. Os excertos que citamos são de cartas trocadas por Anne e Mary, tendo a viajante transcrito as cartas que recebeu da amiga nesses cadernos. 
detemo-nos sobretudo no período da estada em Portugal, chegando a conclusões diferentes das de Gross, nomeadamente no que diz respeito à identificação de figuras históricas com quem Anne conviveu, por exemplo, o "embaixador Melo" que a autora e o seu tutor e protector Horace Walpole referiram nas missivas que enviaram a Mary Berry. Como veremos, e como seria de esperar, em Lisboa, a famosa escultora convive sobretudo com membros da sua classe social, mas detém-se nas paisagens etnográfica e histórica ('mourisca') lusas, descrevendo vários monumentos e hábitos portugueses, quer nas suas cartas para Berry, quer, embora de forma mais superficial, no seu romance Belmour, em que Lisboa e, sobretudo, o Convento da Cortiça, em Sintra, são espaços da acção do capítulo décimo. Como veremos, a viagem da autora permite-lhe ficcionalizar a capital portuguesa (onde, aliás, começa a redigir Belmour) e os seus arredores, de forma realista, a partir das suas próprias experiências e memórias peripatéticas.

A afirmação inicial da introdução de Pere Gifra-Adroher, no seu estudo Between History and Romance: Travel Writing on Spain in the Early Nineteenth Century, aplica-se igualmente à representação de Portugal nos escritos autobiográficos e ficcionais de Damer, sobretudo relativamente a temas relacionados com a história portuguesa, como o "período muçulmano", a religião, a arquitectura gótica e o sentimentalismo:

During the last decades of the eighteenth century and throughout most of the nineteenth-century Spain attracted the Western romantic imagination powerfully. Though anchored in economic and cultural stagnation, Spain offered to post-Enlightenment travelers the exoticism of its Oriental, medieval, and imperial past. A journey to Spain not only entailed a literal geographical progression but also a figurative voyage across different historical and cultural periods of that country, such as the Moorish domination and the Christian Reconquest (711-1492), the Golden Age (ca.1556-1700), and the recent Peninsular War (1808-1814) (...). Once and for all, Spain and Spaniards began to lose their invisibility, becoming more known and, to a certain extent, also commodified by the apparently innocent cultural channels that purported to represent them. (Gifra-Adroher 15) 
As temáticas que abordaremos ao estudar, primeiro, a estada de Damer em Lisboa, e, finalmente, o seu romance Belmour comprovam a conclusão de Gifra-Adroher que acabámos de citar, e permitem-nos analisar, recorrendo a outros relatos de viagem, de que forma Portugal é representado por viajantes na escrita de viagem dos séculos XVIII-XIX e que diálogos intertextuais o romance de Damer estabelece com esses relatos, que seriam, em princípio, menos subjectivos, mas que influenciam a forma como romancistas posteriores textualizam Portugal. Numa primeira parte, analisamos, portanto, a estada de Anne Damer na capital portuguesa, entre 1790 e 1791, a partir das missivas que enviou aos seus amigos, e, na segunda parte, estudamos a representação de Lisboa e Sintra no seu romance sentimental de viagem, como espaços, respectivamente, de convalescença e de evasão que leva à aprendizagem com base em emoções desmesuradas, que, curiosamente, marcam o universo masculino da narrativa ficcional.

\section{A Autora, o seu Círculo de Amigos e a Descrição da sua Estada-convalescença em Portugal [1790-1791]}

A primeira parte deste artigo pretende, evitando cair no biografismo, analisar a representação de Lisboa e da experiência portuguesa da autora, permitindo-nos averiguar que "realidades" Damer incorporou no seu romance em forma de ficção, sobretudo ao nível das paisagens observadas e ficcionalizadas.

Anne Seymour Damer nasceu em Kent, no seio de uma família aristocrata Whig, filha única de Caroline Bruce (née Campbell), Lady Ailesbury (1721-1803), ${ }^{4}$ e do político e marechal Henry Seymour Conway (1721-1795). Infelizmente, no final da sua vida, a autora mandou destruir todos os seus escritos autobiográficos, pelo que, como Noble adverte, em 1908, ao tentar redigir uma biografia da

4. A mãe de Anne é filha do quarto duque de Argyll e mantém o título de condessa de Ailesbury que vem do seu primeiro casamento. Anne tem uma meia-irmã, Lady Mary Bruce, e terá fornecido uma história dos seus antepassados que Joanna Baillie dramatizou como The Family Legend, a Highland Play que inaugura o novo Theatre Royal de Edimburgo, em 1810. Anne poderá ainda ter servido de modelo para a excêntrica personagem Lady Maclaughlan em Marriage (1818), de Susan Ferrier. (Cf. Begg 91) 
autora, "it has therefore been difficult to trace the events of her interesting life". (x) Em Junho de 1767, aos vinte e sete anos, Anne casou com o político Whig, John Damer, filho de Joseph Damer, Earl of Dorchester, Lord Milton (1744-1776), divorciando-se sete anos depois. John Damer estudou em Eton e em Cambridge, e foi membro do Parlamento britânico, como representante de Gatton, entre 1768 e 1774. O marido de Anne viveu uma vida extravagante, contraiu dívidas avultadas de jogo, que o pai dele se recusa a ajudar a pagar, e ele suicida-se, com um tiro, em 15 de Agosto de 1776, na taberna Bedford Arms, na zona de Covent Garden. ${ }^{5}$ Anne - endividada, e sem o apoio da família do marido para pagar as dívidas dele - vive com os seus pais até 1778. Nessa mesma década, tal como na seguinte, vários caricaturistas e autores ingleses representaram Anne como lésbica, que recusava a companhia de homens, sugerindo até que ela fora responsável pela morte do marido, (Gross, "Biographical Note" x-xi) enquanto Angelika Kauffman e Sir Joshua Reynolds pintaram retratos da famosa artista, respectivamente em 1766 e em $1773 .{ }^{6}$

5. Georgiana Cavendish, Duquesa de Devonshire, ficcionaliza a morte de Damer no seu romance epistolar The Sylph (1778).

6. Horace Walpole (1717-1797), primo em segundo grau e amigo de Anne, foi seu tutor sempre que os pais viajaram, e deixou-lhe, entre outros bens, a sua famosa casa neogótica, Strawberry Hill, onde ela viveu entre 1797 e 1811, fazendo as visitas guiadas e cobrando bilhetes aos visitantes, tal como Walpole. Em 1802, Anne viajou até Paris com a (então famosa) escritora Mary Berry (1763-1852), amiga que Walpole lhe apresentara em 1789, e com quem a escultora terá tido um romance. (Schmid 23-69) Walpole e David Hume, que foi Subsecretário quando o pai de Anne foi Secretário de Estado, entre 1766 e 1768, estimularam a sua carreira de escultora, tendo Hume reprovado o facto de a adolescente se rir das escultoras de outros artistas publicamente. Após enviuvar, Anne dedicou-se sobretudo à escultura, tendo exposto na Royal Academy mais de três dezenas de trabalhos (1784-1818), como honorary exhibitor, sobretudo bustos neoclássicos, dela própria e de Lady Melbourne, Lord Nelson, Joseph Banks, George III, Mary Berry, Charles James Fox e das actrizes, suas amigas, Sarah Siddons e Elizabeth Farren, entre outras figuras. (O romance Life Mask, publicado em 2004, por Emma Donoghue, ficcionaliza o romance amoroso entre Damer e Elizabeth Farren) Alan Cunningham, com base em algumas inconsistências nas suas obras de arte, terá alegado que a artista recorreria a assistentes para a ajudar. As duas esculturas em pedra que representam Ísis e o rio Tamisa, que a artista fez para adornar a ponte de Henley-on-Thames (onde passou a sua juventude), ainda hoje podem ser admiradas nesse mesmo monumento. Anne participou em várias peças de teatro, na casa da sua meia-irmã (Richmond House), e, em 1802, levou à cena, em Drury Lane, a comédia Fashionable Friends, de Mary Berry, na qual desempenha o papel de Selina Vapour e lê o epílogo redigido por William Lamb. A peça, embora tivesse sido um sucesso em Strawberry Hill, dois anos antes, deixa de ser exibida passadas três noites. A escultora faleceu em Londres, no dia 28 de Maio de 1828, aos 79 anos de idade, tendo sido sepultada na igreja de Sundridge (Kent), juntamente com as suas ferramentas de escultora, o seu avental e as cinzas do seu cão preferido - Fidele, que falecera, em Lisboa, em Fevereiro de 1791 -, ao lado da mãe, com uma pedra tumular desenhada por ela própria. 
Anne viajou pela Europa com os pais e com amigos, nomeadamente pela Alemanha e pela Holanda, em 1760-1761, pela Alemanha, Holanda e França (Paris) no ano de 1772, pela França e Flandres, entre 1774 e 1775 , e, de novo, entre 1777-1778, e por Itália várias vezes, visitando Roma, Nápoles, onde conhece Lord Nelson (1798), e Florença, entre 1778-1781 e 1785-1786. Em Novembro de 1790, por motivos de saúde, parte para Lisboa, onde permanece entre 21 desse mês e Março de 1791, e onde terá começado a redigir o seu romance Belmour. A viagem não agradou à mãe da artista, e o seu pai esclarece, numa carta dirigida, nesse mesmo mês, a William Hamilton, por que razão Anne não aceitara o convite dele e da mulher para passar, mais uma vez, o Inverno em Nápoles:

she has gone to pass some of the cold months at Lisbon. She was not ill, but only not quite well, the harsh winters here generally affect her, and in point of climate I believe that is among the first. It may seem odd to you, and to all who know her and you, that going so far, she should prefer Lisbon to Naples. To this her inclination would have led her, but she took her resolution late, too late for a journey across the Alps, which would now have been too cold, and too fatiguing for her. I think, besides, that however excellent and pleasing to her in most respects, your air was not quite adapted to her constitution. The voyage to Lisbon is long, but she bears the sea tolerably well; the Paquet boats on that station are excellent; and she has met with the civilest captain and the best accommodations imaginable, this we heard from her at Falmouth; from Lisbon we have not yet heard, tho' we imagine she sailed on the 7th or 8th, and, as appeared to us, had fair winds for ten days or a fortnight afterwards. (Noble 119)

Anne não viajou através dos Alpes, rumo à Itália, porque se atrasou a decidir viajar e porque essa viagem seria, em Novembro, demasiado fria e cansativa. A partida de Anne de Falmouth é atrasada por ventos desfavoráveis, e quando parte é, como a autora informa Edward Jerningham, numa missiva de 6 de Novembro de 1790, num "fine large ship-of-war, with an airy cabin and a good-natured master (...) 
I shall let you know when I land, and that I should land in Portugal." (Bettany 180)

Lisboa era um destino britânico de convalescença, e eram muitos os doentes que se mudavam temporariamente para a capital lusa, como vimos num outro estudo (Puga 2016), sendo a urbe ficcionalizada enquanto tal, por exemplo, no romance Mary, A Fiction (1788), de Mary Wollstonecraft (1759-1797), conhecida sobretudo pelas obras A Vindication of the Rights of Men (1790) e A Vindication of the Rights of Woman (1792), e descrita em inúmeros relatos de viagem que ecoam intertextualmente nesse romance. Mary, A Fiction representa superficialmente Lisboa, sobretudo como espaço povoado por tuberculosos britânicos, imagem que surge na sequência da marcante visita de Wollstonecraft a Portugal, em Novembro e Dezembro de 1785 (para cuidar da sua melhor amiga, Fanny, então doente) e que tem, portanto, como base a sua experiência pessoal num país estranho, como viria a acontecer com as descrições de Lisboa em Belmour. As viagens permitem a essas escritoras testemunhar a vida de várias outras mulheres e comunidades, ficcionalizar a viagem como aprendizagem que é fruto de observação e de comparação intercultural, como até os notebooks de Damer revelam. O que Godwin, marido de Wollstonecraft, afirma sobre a estada dela em Lisboa é válido também para a de Damer, como veremos: "No doubt the voyage to Lisbon tended considerably to enlarge the understanding of Mary. She was admitted into the best company the English factory afforded. She made many profound observations on the character of the natives, and the baleful effects of superstition." (Memoirs 47)

Damer, tal como muitos outros doentes ingleses, por sugestão dos seus médicos, viaja para Lisboa nos meses de Inverno, e essas viagens para fins medicinais rumo ao Sul da Europa (para curar-atenuar a tuberculose) levam, por exemplo, Keats a Roma e, em 1754, Henry Fielding a Lisboa, onde falece, como é sabido. Em 1782, William Hickey (372) alojara-se num hotel onde pacientes ingleses recuperavam, nomeadamente o hotel de Mrs. William, onde se instalavam doentes britânicos, por vezes acompanhados por toda a família. $\mathrm{O}$ viajante descreve quer 
o estado de vários pacientes, ${ }^{7}$ que também escolhem a Itália como destino (tal como Anne fizera), quer o quotidiano desses estabelecimentos, ambiente que Anne evita ao ficar numa casa própria: "there were also several other male invalids, all of whom assembled every morning in the coffee-room, a noble apartment (...). Here I usually employed an hour or two daily in reading English and other newspapers and admiring the beautiful scenery from the Windows (...). Several of the invalids daily sinking into the grave." (Hickey 373) Um guia publicado, em 1870, pelo médico Michael C. Grabham, sobre a Madeira e Portugal continental, para pacientes britânicos e familiares, refere esse tipo de estabelecimentos em Lisboa: "Mrs. Durand, also, in Rua dos [sic] Flores, has a house well situated and adapted to the requirements of invalids and families." (Grabham 197) Como informa Jeremy Black, em Inglaterra, a ida às termas locais foi gradualmente substituída pela "health travel" no século XVIII: "to travel abroad for health represented a fusion of two of the more important developments in upper-class activities in this period: tourism and travelling for health". (205) No entanto, a partir de 1860, os viajantes-doentes britânicos passariam a preferir a Riviera francesa, (Pemble 85-86) mudando-se para novas zonas quando os antigos sanatórios de Inverno eram invadidos por pacientes-turistas e ficavam sobrelotados. A viagem por motivos de saúde de Damer remete, assim, para o turismo de saúde e para a climoterapia, no âmbito dos quais Portugal continental e o arquipélago da Madeira eram destinos frequentes e espaços de convalescença, ou "blessed borderland of convalescence." (Shand 546) Esse fenómeno é atestado por obras anónimas como The Diary of an Invalid: Being the Journal of a Tour in Pursuit of Health in Portugal, Italy, Switzerland and France in the Years 1817, 1818, and 1919 (1820), de Henry Matthews,

7. "I could not help feeling extremely interested for one very elegant young man who stood in this class. His name was Richardson, only two-and-twenty years of age and in possession of a large estate in Devonshire (...).The physicians, pursuing the customary routine, began their operations at his own house, then ordered him to Bristol hot wells, and finally to Lisbon, where he had been two months when we arrived. He grew gradually weaker and weaker, so much so that at last he with difficulty could crawl from his bed-chamber to the coffee-room assisted by the arm of his servant, yet (...) he thought not of death. On the contrary, he talked with confidence of future plans that he intended carrying into effect, remarking that as he did not think he had derived any material benefit from the climate of Lisbon he would return home for the summer months, and if it proved necessary that he again should move he would try Italy". (Hickey 373-374) 
A Letter to an Invalid about to Visit the Island of Madeira (1834), A Brief Letter of Advice to an Invalid, in Reply to a Request for Information about Madeira as a Winter Residence, by an Ex-Invalid (1859), ou ainda A Sketch of Madeira: Containing Information for the Traveller, or Invalid Visitor (1851), de Edward V. Harcourt. ${ }^{8}$ A estada da autora em Lisboa é, portanto, forçada (pela doença) e leva à escrita, como a própria indica a Berry, tendo, por essa razão, começado a redigir Belmour em Lisboa. As viagens de Damer pelo Sul da Europa permitir-lhe-ão utilizar esses cenários pitorescos, exoticizados e distantes como espaços estrangeiros da acção no seu romance, nomeadamente Lisboa, ou seja, a experiência pessoal da autora-escultora-viajante é inscrita na sua ficção.

Após sete dias de viagem, Anne chega a Lisboa no dia 17 de Novembro de 1790, e, quatro dias depois, queixa-se dos vidros partidos na janela da sua residência em Lisboa e da indolência dos portugueses: "You cannot form to yourself an idea of the Portuguese, their indolence or indifference, neither money nor entreaty will bring them. When I came I found two panes of glass broken, and for five days, though the master of the house and my own servants went twenty times a day after the people, I could not have them put in. I can divert myself with all distresses of this sort except cold ones," (Noble 122) descrevendo ainda o seu quarto em Lisboa, onde se isolava para descansar, ler, reflectir e escrever:

My cabinet (...) It is a small, white-washed, and a sort of farm-house chimney occupies one-half of it; ${ }^{9}$ its is high and built with large, rough stones; there are some shelves, two tables, and many chairs; here I have my books and my writing, and my ideas are not at least outwardly frozen (...).Their substitutes for fires are large cloaks, of the form you see in Florence, which they wear very gracefully - men and women. They are eternally wrapped up in them, riding, walking, hanging over a balcony when the sun shines, or sitting at home in a state of idleness, a state to which they seem to have a great propensity, by what I hear and by the little I have seen. (Lewis 1, 272)

8. Sobre as viagens de inválidos britânicos para o estrangeiro, no século XIX, veja-se Frawley (113-155).

9. O quarto de Anne é semelhante ao quarto ficcional de Emily em Lisboa. (Gross, "Introduction" xxiv) 
Estas notas permitem-nos concluir que Anne viaja com empregados, leva livros ingleses, um dos quais ainda não publicados quando ela deixa Londres, ${ }^{10}$ e material de escrita, actividade com a qual se ocupa em Portugal. A escultora refere ainda traços comportamentais estereotipados dos portugueses, como a ociosidade, que encontramos em muitos outros relatos de viagens, entre outras apreciações sobre os portugueses, cujos hábitos e vestuário de Inverno (mantos) compara aos dos italianos, num breve exercício de comparação intercultural, permitido pelas viagens anteriores da autora, que já referimos, como acontece também quando compara o Aqueduto das Águas Livres à Ponte do Gard. Os estereótipos remetem para a formação e manutenção de ideias de características nacionais que sustentam o nacionalismo (que é também um fenómeno cultural), e já em Sevilha, Anne saiu à rua vestida "à portuguesa" e os transeuntes chamaram-lhe francesa e correm atrás dela. (Noble 129) Intimamente ligada à questão da nacionalidade, a língua portuguesa é aprendida pela viajante, embora talvez não da forma tão "ridiculamente fácil" como a própria afirma: "it only deserves the name of a dialect, and to those who have learned other languages, is ridiculously easy. I am told too, that when I learn Portuguese, I shall be able to read Spanish, as they all do, without learning it." (Lewis 1, 273)

Relativamente a outros símbolos nacionais e à encenação do poder régio, em 31 de Janeiro de 1791, a escultora diverte-se a visitar o molde da estátua equestre de D. José I (que talvez seja o que se encontra no Museu da Cidade de Lisboa), encontrando-se a estátua já na Praça do Comércio (a que a autora chama "Great Place"), desde Maio de 1775. Anne Damer elogia o monumento:

10. Numa carta que envia a Mary Berry, em 27 de Maio de 1791, Anne confessa-lhe que, antes de ela partir para Lisboa, o seu livreiro lhe oferecera uma cópia do novo livro de Edmund Burke (Reflections on the Revolution in France) antes de ser publicado (em 1 de Novembro de 1790), para que o pudesse ler e levar. (Melville 35) 
I returned from the morning party as much fatigued and no more amused than I expected. It was to see armouries and founderies, all of which I have seen and re-seen at other places. I could not avoid going, as among other things I was to be shown the model of the statue in the Great Place here. The statue is colossal, of bronze, of Joseph I., the late King. It was modelled and cast at Lisbon, and though heavy, really is not without merit.

Como é sabido, a obra de arte é da autoria do escultor Joaquim Machado de Castro, foi a primeira estátua equestre realizada em Portugal, o primeiro monumento escultórico público a representar uma pessoa (então ainda) viva, e ainda a primeira estátua de tamanho monumental a ser fundida de um só jacto, em Portugal, e uma das primeiras em todo o mundo, processo que é descrito, em 1810, por Machado de Castro na Descrição Analítica da Execução da Estátua Equestre Erigida em Lisboa à Glória do Senhor Rei Fidelíssimo D. José I.

Em Janeiro de 1791, Anne refere as igrejas góticas, algumas em ruínas, imagem que convoca o Terramoto de 1755: "Though there are so many things to see at Lisbon, there are some - some respectable Gothic churches - which will bear seeing more than once. One of the most ancient is horrid to look at, almost totally destroyed by the earthquake, little else but the outside walls standing. This church they are slowly attempting to rebuild in the Gothic style, but I doubt the success," (Lewis 1,333 ) Muito provavelmente, a autora - que se assume mais uma vez como autoridade na área da História de Arte, do gótico e do restauro de edifícios - refere-se provavelmente às ruínas do Convento do Carmo, que o romance Mary, A Fiction (1788), de Mary Wollstonecaft, que talvez Damer lera, também refere: "she passed by the ruins of an old monastery on a very high hill; she got out to walk amongst the ruins". (119) A artista-viajante continua a descrever ruínas e locais pitorescos da paisagem de Lisboa, que bem poderiam ser espaços de acção de romances góticos: 
The Castle, formerly a Moorish palace, was nearly made a ruin. You see here and there a little bit of a column, etc. stuck in little better than a mud wall, but this her Majesty does not think of rebuilding; she has at immense expense built a church called the Convento Nuovo or the Coracão de Jesu (the heart of Jesus) in the worst taste, adorned by many colossal statues in the style of Bernini exaggerated. The works of a Portuguese artist in this church, the great altar-piece, and several others, are repainted by Pompeo, and one by the Princesses. (Lewis 1, 333-334)

A viajante reagiu negativamente à fé e práticas católicas da Corte portuguesa, e se era a favor da Revolução Francesa, era uma protestante convicta, sendo-lhe difícil até descrever um convento, apesar de Belmour representar a personagem Don Juan a chorar pela sua amada morta, Rosaura, num convento em Sintra, onde Belmour apre(e)nde o verdadeiro valor do amor, (Gross, A Life 155) tratando-se decerto do Convento da Cortiça, que também Byron e Hobhouse visitariam e descreveriam. O católico assume-se como "definitional other" (Parker et al. 5) no que diz respeito à auto-definição da maioria dos britânicos (protestantes), e o tópico do católico demonizado ou carnavalizado "habita" o imaginário literário britânico coevo, sobretudo nas obras que fazem parte da Protestant Imaginative Writing. (Shell 1-2) Aliás, The Lisbon Guide (1800), dedicado a "invalids who visit Lisbon", refere essa mesma curiosidade e o espanto dos britânicos (para quem os católicos são estranhos demonizados): "the ceremonies of the Popish religion, especially on particular festivals, are naturally objects of curiosity to an Englishman; but however they may amuse, they cannot please (...) bigotry and atheism are found together in Lisbon." (15)

No excerto dos notebooks de Damer, que citámos acima, a viajante refere a reconstrução de Lisboa pela Rainha D. Maria I, que governou entre 1777 e 1816, nomeadamente o facto de não restaurar o pitoresco e medieval castelo dos mouros e ter erguido, juntamente com a Basílica da Estrela, o dispendioso Convento do Coração de Jesus (mosteiro feminino da Ordem das Carmelitas Descalças), horrivelmente ornado, na sua opinião de artista, que parece não se interessar pelo estilo barroco, símbolo da exuberância e do espectáculo católicos. A construção 
do edifício, que apresenta características dos estilos barroco final e do neoclássico, começou em 1779 e terminou em 1790. À semelhança do que acontece com outros viajantes protestantes, as visitas a conventos espantam a autora, e sobre o Convento do Coração de Jesus, afirma:

In this convent is the Queen's favourite nun, recommended to her by the late confessor as a santa; they say she is really a shrewd, sensible, woman, and spoken well of. There were, they say, many fine pictures in the church by the best masters; most of them walled up or destroyed, some stolen and sold. At the Marquis Pamela's [sic.] there is one called a Rapahel, which it may be; it is very fine, but has been miserably painted over, which I gained much credit by finding out, though it is as plain as the nose on one's face. (Lewis 1,334)

Esta última referência autocaracteriza a artista como informada em termos de História de Arte e como tendo feito um favor (reconhecido e agradecido) à comunidade local. Em Novembro, Anne janta na casa do embaixador britânico, que descreve com vivacidade:

I dined at our Minister's last Thursday, with not how many English of the sort no foreign town is free from - fat, vulgar women, and scowling, unknown men, consuls, and some of the Factory. In the evening we had the French Ambassadress (Madame de Chalons) and all the Corps Diplomatiques (...) I should like to see something of the Portuguese, which is not very easy for foreigners. (Lewis 1, 271)

O embaixador (ministro plenipotenciário) referido pela autora era Robert Walpole (1736-1810), primo de Horace Walpole e sobrinho do Primeiro-Ministro (Whig) Sir Robert Walpole (1676-1745), que governou entre 1721 e 1742 . Robert foi secretário da embaixada de Paris (1768-1770) antes de ir para Portugal como enviado extraordinário e ministro plenipotenciário, entre 1771 e 1800, casado, desde Junho de 1785, com a sua segunda mulher, Sophia Stert (m. 1829), filha do mercador Richard Stert, também residente em Lisboa, inglesa que Anne refere no excerto que transcreveremos 
mais adiante. A autora confessa, após referir os seus compatriotas que residem na capital portuguesa, a sua curiosidade por saber como vivem os lusos: "I should like to see something of the Portuguese, which is not very easy for foreigners," (Lewis 1, 271) e tenta conviver com eles para os conhecer melhor, evitando os círculos aristocráticos, apesar de tal não lhe ser totalmente possível, pois, por exemplo, Charles O'Hara visita-a em Lisboa, quando regressa de Gibraltar para Londres, e ela conhece os reis de Portugal e convive com o embaixador Walpole e com a sua mulher, que lhe mostram a cidade, como a própria descreve: "Nothing can be more civil and attentive than the people in general are to me here - Mr Walpole, our Minister, and his wife, in particular." (Lewis 1, 271)

Walpole guia a artista ao longo de Lisboa: "Mr. Walpole is to carry me to a grand fête at a Portuguese house, given on the marriage of a great heiress, who has married her uncle, as she could find no one great enough to marry out of her own family," (Lewis 1, 271) e Anne queixa-se ainda dos hábitos sociais lusos, pois as visitas domésticas nocturnas acontecem demasiado cedo: "The hours are early; sometimes they begin to make visits at five o'clock, and everything ends at latest, unless it be some fête, but eleven," (Lewis 1, 271) enquanto, noutro exercício de descrição do Outro, refere que os nobres portugueses se sentavam, até há pouco tempo, no chão de pernas cruzadas, e ainda observa uma mulher triste "of the first rank" assim sentada. (Lewis 1, 272) A questão do género influencia obviamente a vivência diária dos portugueses, e como mulheres casadas não podem frequentar a casa de homens solteiros, "tho' their husbands were there dancing away and enjoying the fête", a festa oferecida pelo duque do Cadaval não tem muitos convivas. A autora critica a falta de liberdade das mulheres em Portugal e conclui sobre os hábitos lusos: "I would have nations polish, but I wish the polish could be given to their own national customs and manners, and not the manners of other nations always attempted, for if manqué nothing can be worse." (Lewis 1,273) No dia 2 de Dezembro de 1790, Anne queixa-se da dificuldade de viajar pelas colinas de Lisboa, sobretudo devido ao estado do pavimento público e às carruagens: 
Going out in Lisbon is an operation (...). There are in general only two-wheels chaises, open before, with leathern curtains that draw: you set out as if on a journey, and go nodding along over the worst pavement commonly, or the worst road, and up and down very steep hills, on which this town stands; yet these chaises are actually the vehicles best calculated for this town, and far from unpleasant when one is not obliged to be much dressed; but you may guess how it is when you have to scramble up into such a carriage in rainy weather, with a gauzed petticoat, and a dressed head. A four-wheeled carriage is so uneasy: it is, I think, scarcely bearable. These are used (but not without four mules) by ministers and great persons, and here and there a foreigner, but there is no such thing to be hired unless by chance. My own coach, were it here, might be drawn up the hills by six mules; but would never be kept back by two, such as they have for the town. You will imagine all this diverts more than disturbs me. (Lewis 1, 271)

A autora comenta, assim, longamente a dificuldade de uma mulher (de classe social elevada) viajar nas carruagens lusas, e essa referência não é de admirar, pois, já William Hickey concluíra, em 1782, que "a carriage was an indispensable requisite at Lisbon". (374) No início de Dezembro, a viajante avista o aqueduto de Lisboa e enumera vários elementos da paisagem portuguesa:

Here you have a corn-field, an orange garden, a church, and then a house, just as it happens, all jumbled in the same queerest manner that I ever yet saw. The aqueduct may be called magnificent; but the arches are, I think, too close: the height in one part is immense; it looks rather thin and poor than light $(. .$.$) the place is wild and rocky, with some gardens of$ orange trees, now ripening, and some olive trees. I do not love comparisons; but there is no seeing this place without thinking of the Pont du Gard, and sadly indeed it loses by such comparison, though the one is all in its glory and the other but a ruin. (Lewis 1, 272)

Numa segunda visita ao aqueduto, no final do mesmo mês, o monumento de arcos "góticos", visto de perto, já lhe agrada mais, e Damer reescreve o que afirmara antes, "I fancy there is not such 
another in the world (...) I owed it this réparation d'honneur, as I believe my first account to you was not favourable." (Lewis 1, 273) O acto de viajar permite acumular aprendizagens e mudar de opinião; daí que a escultora corrija opiniões que veiculara anteriormente. Face ao processo de dépaysement, a autora enumera micro-paisagens de Lisboa e confessa o seu espanto perante a novidade da (con)fusão desses elementos paisagísticos naturais e humanizados, incluindo árvores que são raras no Reino Unido como as oliveiras e as laranjeiras, descritas num ambiente selvagem e rochoso, ou seja, pitoresco e estranho, recorrendo Damer ao exercício da comparação para que a destinatária da missiva possa visualizar o aqueduto sobre o rio Gard (século I a.C.), convocando assim a imagem da ponte francesa, que tem quarenta e nove metros de altura e sustenta um segmento curto do aqueduto romano de Nîmes, no sul da França, que leva água de Uzès até à referida cidade e que mede cinquenta kms. Portugal é, assim, também um espaço de aprendizagem intercultural.

No dia 17 de Fevereiro de 1791, Anne informa Mary: "my mules are on the road, and will be ready on Monday next, and that evening or Tuesday I shall probably cross the water and begin my journey, from that time I leave Lisbon till I arrive at Madrid, I shall not have a single letter." (Lewis 1, 335) No dia 20, Anne deixa Lisboa desagradada com o clima, (Lewis 1, 334) rumo a Espanha, e fica alojada na Aldeia Galega numa casa particular, seguindo o percurso habitual, até Elvas, onde é recebida, como Horace Walpole informa as irmãs Berry, "with all military honours and a banquet, by order of Mello, formerly ambassador here [London]. It was handsome of him, but must have distressed her who is void of all ostentation and love of show." (Lewis 1, 297) Por seu turno, Anne confessa, já em Herrera (19-03-1791), que esse episódio em Elvas e o facto de os ibéricos serem tão "very civil" lhe deu "a more than common horror of being shown civilities." (Lewis 1, 340). Trata-se, não de "Francisco de Melo", como Gross (The Life, 152) refere, indicando as datas Dezembro de 1766, 1768-1769 (datas em que o embaixador em Londres é, na verdade, Martinho de Melo e Castro) e Setembro de 1772, e só nesse último período é embaixador Francisco de Melo e Carvalho (que permanece 
em Londres entre Fevereiro de 1770 e Julho de 1774). O estudioso confunde os dois embaixadores, sem ficar claro a quem se poderia referir como governador de Elvas, que Anne não nomeia, mas que a nossa investigação nos permitiu identificar. Em 1791, o governador de Elvas era, já há uns anos, o Marechal de Campo Manuel Bernardo de Melo e Castro, também Governador das Armas da Província do Alentejo, e irmão de Martinho de Melo e Castro (1716-1795), que foi, de facto, embaixador em Inglaterra entre Maio de 1756 e 1762, e, de novo, entre Janeiro de 1764 e Dezembro de 1769, tendo sido posteriormente Ministro da Guerra e Primeiro-Ministro, e que é referido na correspondência de Horace Walpole $(308,383)$ como embaixador português.

A autora explica a Mary Berry que "Elvas, the last town in Portugal, is in perfect repair, to appearance, and a remarkably pretty town," (Lewis 1, 336) descrevendo a sua chegada à cidade, onde é recebida com honras militares:

Elvas being the frontier town in Portugal, I was told to ask for a letter to the Governor, that my baggage might not be stopped. This happened to be the brother of old Mello's, who was in England many years, and much at my father's house before you were born. ${ }^{11}$ Besides giving me a letter, he chose by way of a fine thing to write to the Governor his brother, who chose to order that I should be received with the honours of war. Some miles from the town I met a guard of thirty horsemen who escorted me, and I came into the town, drums beating, trumpets sounding, and cannon firing (it is literally true); was dragged to the Governor's house instead of going quietly to my inn, and sat down almost instantaneously to a great dinner with a dozen or fourteen officers; they carried me all over the town, and with the greatest difficulties I got rid of the company in the evening by saying, what was too true, that I was so much fatigued I must go to my bed. (Lewis 1, 340-341)

Este tratamento especial seria raro para uma mulher, sobretudo para uma mulher inglesa, servindo como estratégia de auto-singularização

11. Mary Berry nasceu em 1763. 
através de um imaginário bélico e militar, ou seja, à data, associado ao universo masculino.

Em Espanha, a autora visita Badajoz, Sevilha (06-03-1791), Granada, Córdoba, Toledo, o Escorial, Il-de-Fons, Burgos e Valadolid - onde terá visitado um mosteiro dominicano, cuja arquitectura gótica poderá ter servido de base para descrever o mosteiro português em Belmour, (Gross, "Introduction" xxv) - e posteriormente, já na França, visita Bayonne (24-02-1791), Bordéus, Paris (03-05- 1791), e regressa a Londres em Maio. ${ }^{12}$ Em Sevilha, a autora confessa ao seu amigo Edward Jerningham o espanto perante o clima e a paisagem etnográfica da Andaluzia, onde lhe apetece passear mais do que em Lisboa:

I am glad that you like my coming to Spain. I rejoice that I did not give up my idea (...); but the weather has been hitherto all I could wish. Were it hotter, it would be too much, if not for me, for mules and men. - The climate is so soft here, such remains of antiquity, something so dignified in every thing I see, and the people so very different from the rest of Europe, and so queer and national, so like another world, that I feel much more indeed to take root at Seville than I did at Lisbon. I think being a fine orange tree in a Moorish garden, with cooling fountains continually playing round one, must be a pleasant existence. - But fata vocant; and tomorrow early I mean to set out for Granada. (Bettany 181)

Já em 28 de Maio de 1803, ao escrever a Berry, Anne avalia a sua viagem a Lisboa, com alguma distância crítica: "I took the voyage to Lisbon for my own health once. As a party of pleasure or amusement, or from an idea of any relief to my spirits, I certainly think such voyages would out-weigh the advantages, particularly when added to the present state of things." (Melville 276) Em 2 de Setembro de 1808, a autora regozija-se da vitória das tropas inglesas (Batalha do Vimeiro,

12. Em 16 de Maio já envia uma carta, de Londres, a Mary Berry, referindo as muitas visitas que recebeu. (Melville 27) 
21-08-1808) face ao exército de Junot em Portugal, no âmbito da Guerra Peninsular:

I cannot resist the chance of being the first to give you the great and really glorious intelligence of the success of our own Arms. General Junot (...) came out with his Army and attacked the English, about eight leagues from Lisbon. A battle ensued in which our troops were completely victorious, and the French retreated into Lisbon. The consequence was an immediate offer of capitulation (...) I only at present know this from the Times, but I do and will believe (...) I can think of nothing but Lisbon and our Victory (...). Poor, mistaken $\mathrm{O}^{\prime}$ Hara! Had he lived, which I think he would, had you lived with him, how should we not have at this moment exulted and rejoiced! (Melville 292)

A estada da autora na Península Ibérica permite-lhe, quer comparar várias realidades e formas de ser e de viver, quer recolher paisagens que reproduzirá ao representar os espaços pitorescos e distantes no seu romance, que analisaremos de seguida.

\section{Representações de Lisboa e Sintra em Belmour [1801]}

O seu único romance, Belmour, redigido entre 1791 (e, portanto, começado em Portugal) e 1797, é publicado anonimamente em Julho de 1801 (3 volumes), e um dos capítulos do segundo volume (capítulo 10) ficcionaliza a estada do protagonista na capital portuguesa e foi inclusive referido por Mary Berry, que lê o manuscrito, entre Abril e Agosto de 1797. (Gross, "Time Line" xv) Excluindo a edição mais recente, que utilizamos (2011), preparada por Gross, o texto teve três edições, a de Londres, em 1801, a de Dublin, também nesse ano, e uma reedição em 1827, bem como uma tradução francesa, em 1804 (autoria: Mme Houdon). Em 1802, a Monthly Review publicou uma recensão do romance anónimo que afirma: "considerable talents are here displayed in the support and delineation of characters, accompanied by many just reflections, and a knowledge 
of the world", (Art. 21, 314) criticando a conduta imoral, quer de Lord Belmour para com Lady Roseburg, quer de Emily Courtenay, casada, ao dar esperança ao seu antigo admirador, concluindo sobre a moral da autora: "We cannot deem the author's moral sentiments quite correct, who holds up such characters as worthy of our perfect approbation and esteem". O recensor continua a avaliar a obra e afirma:

from the general accuracy of style in this novel, we were surprized at the expressions "solicitations" and "complacence of feel". The recurrence, also, of the word 'uncommonly' is tiresome, and the use of the participles (...) gotten is unpleasing to the ear, though grammatically proper. The narrative would have been better conducted, if the early life of Miss Melville had not been introduced so late, as an episode. (Art. 21, 314)

Gross refere os temas autobiográficos do romance, nomeadamente a paixão romântica, a distância erótica entre seres apaixonados e a influência negativa de mentores egoístas, adiantando: "Anne Damer began Belmour in Portugal. By writing a novel, she could evoke the comforting presence of Mary Berry, confronting her feelings for the young woman in the voice of a male suitor named Belmour. While sometimes read as a window into her private life, however, Belmour conceals as much as it reveals". ("Introduction" xvii) O estudioso cita uma carta de Berry para Damer, na qual a amiga da autora afirma "I am going to pass an hour with Lord Belmour. I dare to say we shall both of us think of you", (Gross, "Introduction" xvii) para sugerir uma identificação entre Berry e o protagonista masculino do romance e concluir que essa personagem seria um substituto (no romance) para Mary Berry, que seria, assim, mais facilmente aceite pela moral da sociedade de então. Num outro estudo, Gross chega mesmo a afirmar: "while in Portugal, Anne Damer fell in love with Mary Berry through their intense 
correspondence, preserved in her Notebooks ${ }^{13}$ at the Lewis Walpole Library and transmuted into fictional form through the attachment of Belmour for Emily Melville". (Gross, "Childish Ways" 196) Antes de Gross ("Introduction" xxii) recorrer a elementos (auto)biográficos da autora e de Mary Berry para contextualizar a produção de Belmour, que considera um roman à clef que ecoa a referida relação amorosa, já Elfenbein afirmara que "Belmour extends the strategy of Damer's sculpture. It denies the marginality that such rumours imposed on her by showing her ability to participate in major literary trends of the day, such as the psychological novel". (108) Se se trata de uma declaração de amor ou de um exercício imaginário de (des)encontros amorosos, torna-se significativo que o título do romance, que consiste no nome do protagonista, signifique "belo amor", e ecoe intertextualmente o do libertino Bellmour da comédia The Old Batchelor, a primeira peça de William Congreve (1693), o nome (Belmour) do destinatário do lamento do poema "Life Unhappy, Because We Use it Improperly" (1760), de Henry Cawthorne, e ainda o nome da viúva Bellmour (Belmore), da comédia The Way to Keep Him (1760-1761), de Andrew Murphy.

A acção do romance tem lugar maioritariamente em Inglaterra, mas, tal como Childe Harold faria, anos mais tarde, Belmour viaja pela Europa, permitindo a Damer servir-se de e intensificar temáticas como o "uncanny" e a melancolia. (Gross, "Introduction" xviii) Lisboa surge no horizonte geográfico da acção por motivos de saúde. O estado de saúde de Lady Caroline, que se vê rejeitada pelo homem que ama,

13. Os notebooks da autora (1789-1797) actualmente na Lewis Walpole Library (Yale University), contêm transcrições de cartas de Mary Berry para Damer, transcritas por esta última, informando os "finding aids" desse espólio no catálogo da biblioteca: "The notes refer primarily to their passionate friendship and confidence in each other; their ill health, both mental and physical; and introspective commentary upon the reasons for their melancholy moods (...) Berry describes their friendship as having 'become such a part of myself, or rather of something much dearer than myself, that I can neither live without it, nor dissatisfied with it, nor with the idea of ever being deprived of it.' In vol. 2, she mentions she has waited all day for her correspondent to visit her, having hoped that each carriage passing by will stop at her door. Elsewhere, she complains that her friend is leaving for Tours without her and of feeling 'continual pains in my head, restless nights \& miserable feels of weakness \& langour.' Other excerpts address Berry's thoughts on William Fawkener, Damer's suitor; Damer's persecution by the press; a crisis in their friendship at the end of July 1794 resulting in Berry's desire to distance herself from Damer socially, and then her decision to weather out the public attacks on their relationship; and Berry's secret courtship by General Charles O'Hara and its disintegration." (https://orbis.library.yale.edu/vwebv/ holdingsInfo?searchId=2061 \&recCount=50\&recPointer=17\&bibId=8127054) 
agrava-se após a morte do seu pai, e "immediate change of climate was recommended by the physicians as the only chance of saving her from decline." (Belmour 94; doravante indico apenas a página do romance). A viagem a Portugal por motivos de saúde é, tal como no romance de Mary Wollstonecraft, um episódio realista, pois, como vimos na primeira parte, até a escultora romancista residiu por esses mesmos motivos. O narrador continua a explicar: "Belmour, alarmed for his sister, instantly determined to accompany her to Lisbon, and from that moment, was wholly occupied with preparations to make the journey as easy and tolerable as possible to her, who, naturally of a gentle, timid nature, was now, from illness and depression of spirits, wholly incapable herself of making the least exertion." (94) A doença torna-se assim um tema do romance, e Lisboa foi a escolha óbvia para a recuperação de Lady Caroline, que terá companhia masculina ao longo da viagem e da estada na capital portuguesa, pois, como vimos na primeira parte, há décadas que Lisboa era um destino de Inverno para pacientes britânicos e para os seus familiares, e a cidade torna-se também um espaço de reencontros. A irmã de Belmour volta a encontrar o seu amado, já casado, na capital lusa e Belmour leva, de Portugal, a aprendizagem do amor.

A viagem dos irmãos, tal como a de Damer, faz-se por motivos de saúde e começa em Falmouth, onde Belmour avista Derville que fizera a irmã sofrer por amor, e cuja mulher, doente, fora também aconselhada pelo médico a viajar para Lisboa "as affording the most likely chance for her recovery". (100) No entanto, a personagem masculina é descrita de forma negativa, como calculista, que não conta a Belmour o outro motivo da viagem: a mulher dele herdaria uma fortuna de um familiar, um comerciante que morava há muito em Lisboa e de quem Mrs. Derville era a única herdeira. Os passageiros dos barcos para Lisboa, tal como acontecera a Anne, ${ }^{14}$ ficam retidos vários dias em Falmouth devido aos ventos desfavoráveis, e os irmãos e o casal

14. Numa carta para o amigo Edward Jerningham, redigida em Falmouth (06-11-1790), antes de partir para Portugal, a escultora informa: "That you may not think me rolling on the Atlantic, or pitching in the Bay of Biscay, I must write you a few lines to tell you that here I am composedly in a tolerable hotel, the wind quite contrary, violent, and, they say, not likely to change for some days. - All this next week, if you write to me, direct to The Post Office, Falmouth." (Bettany 180) 
Derville embarcam em barcos diferentes rumo ao mesmo destino geográfico, sendo Belmour descrito isolado, no deque do barco, a sentir-se a abandonar a terra natal com um "melancholic look towards the shore $(\ldots)$ lost in vague reverie $(. .$.$) with a sentiment of tender melan-$ choly," (101) sentimento que acentua a sensação de afastamento de Emily Melville para sempre. Como este excerto demonstra, os termos do campo semântico da melancolia são recorrentes e adensam as temáticas do amor, do afastamento e da partida, rumo ao final feliz da acção, ou seja, ao reencontro harmonioso, durante o casamento do casal protagonista. Por entre resumos e elipses, os viajantes chegam a Lisboa, que se assume, tal como para Anne Damer, como espaço de melancolia, saudades dos seres amados, reflexão, sentimentos agudos e da descoberta do Outro que a viagem permite. Belmour é também um romance de viagem, que acarreta a comparação intercultural, nem que nas entrelinhas. Tal como a viagem da romancista, também a das personagens é marcada por uma tempestade e dura sete dias, até que os vários barcos ingleses entram no porto de Lisboa: "The extreme beauty of the scene charmed and delighted the elegant taste of Belmour: Lady Caroline, wholly occupied by the renewal of sentiments fatal to her repose, which the unexpected meeting at Falmouth had occasioned." (101-102) A descrição da paisagem é altamente psicológica, pois o narrador privilegia a percepção de Caroline, entristecida pelo reencontro (des)amoroso em Falmouth. Aliás, todo o romance é bastante marcado pela representação dos pensamentos e sentimentos das personagens, caracterizadas sobretudo psicologicamente, nos diversos espaços da acção, nomeadamente em Lisboa, onde Caroline reencontra as emoções de que tentava fugir, e Belmour é confrontado com o seu doppelgänger e Outro religioso, o frade que materializa os mistérios do amor sem barreiras, uma vez que a expedição permite uma certa liberdade e o distanciamento que possibilita ao inglês percepcionar a realidade de forma diferente, pois, a viagem romântica é "a fundamental trope for aesthetic and psychic exploration" e o viajante romântico prefere "unprogrammed, nonchalant itineraries; the suggestive magic of distance and wildness; the excitement of tactile engagement; the equation of strangeness with authenticity." (Cardinal 
147) As referências à melancolia e ao efeito psicológico e até físico que a paisagem e a realidade do Outro despertam nas personagens peripatéticas recordam-nos as palavras de Todorov $(289,293)$, ao defender que as viagens "exterior" e "interior" não se excluem mutuamente, tendo o período romântico privilegiado o "sujeito observador" em vez do "objecto observado", levando, por exemplo, à auto-descoberta; daí que Belmour conclua, durante a sua viagem-aprendizagem que ama Emily e deve regressar e lutar por ela.

A viagem a Lisboa, rumo ao Outro, é também uma viagem interior, pois a comparação-identificação entre Belmour e o frade espanhol funciona como um momento epifânico. Aliás, o religioso chega a comparar o sofrimento de ambos, (290) pois se ele está na cela de um convento, a sua evasão do mundo é semelhante à de Belmour, que viaja e se isola numa metafórica cela peripatética que a viagem física também permite. Há, portanto, um paralelismo entre ambos, sobretudo no que diz respeito ao amor como experiência religiosa, que isola o ser humano do mundo. (110) O frade - que mais tarde confessará, através de uma analepse, que viera para Portugal expulso pelo seu pai - é encontrado, por Belmour, a chorar pela sua antiga amada, cuja morte o levara a tornar-se religioso, após uma vida de excessos, vícios e orgulho (na Corte espanhola) que, aliás, levara à morte de Rosaura. Tal como Belmour relativamente a Emily, também o frade abandonara Rosaura em Lisboa e regressara a Madrid para casar por conveniência do seu pai e esquecera Lisboa e Rosaura. Quando esse casamento não se concretiza, volta a Portugal para descobrir que a sua amada se refugiara repentinamente num convento e falecera, de desgosto. $\mathrm{O}$ frade considera-se o assassino de Rosaura, e Belmour estabelece um paralelismo entre a partida do religioso para Espanha e a sua partida para a Europa continental. $\mathrm{O}$ anónimo frade entregou-se totalmente à memória da amada e continua a materializar um amor intenso e fiel, que, tal como o de Belmour por Emily, é diferente do da maioria das relações no universo do romance, nomeadamente a do casal Derville. Este episódio, e consequentemente, os interlocutores masculinos [recorde-se que Belmour apela à imaginação e confessa a sua melancolia, e o frade reconhece a sua "extreme emotion", (115) 
são marcados por um sentimentalismo excessivo, típico de romances sentimentais do século XVIII, como, por exemplo, Pamela, or Virtue Rewarded (1740), de Samuel Richardson, os famosos romances de Laurence Sterne, Julie, ou la Nouvelle Héloïse (1761), de Jean-Jacques Rousseau, Vicar of Wakefield (1766), de Oliver Goldsmith, Die Leiden des Jungen Werthers (1774), de Goethe, e Castle Rackrent (1800), de Maria Edgeworth, entre tantos outros, que foram posteriormente ridicularizados, por exemplo, por James Joyce, no episódio "Nausicaa", de Ulysses (1918-1920). O sentimentalismo dessas duas personagens masculinas é ainda acentuado por outro episódio, pois, antes de partir para Inglaterra, Belmour visita o frade de novo, que lhe revela estar informado sobre os problemas políticos da actualidade, mesmo estando isolado do mundo, e se despede do forasteiro a chorar.

Em Lisboa, a senhora Derville, ciente de que o marido não a ama, tenta aliciar todas as pessoas de quem ele gosta, incluindo, Lady Caroline, de quem se torna amiga íntima, tal como de Mrs. Marsden. Os ingleses passam as manhãs a conviver, "in drives and rambles, or sometimes excursions by water on the enchanting bay, to visit the surrounding coast, and view the city from the different points on the opposite hills, from which its beauty and magnificence appear most striking." (103) À noite, o grupo faz companhia a Lady Caroline, cuja doença a obriga a recolher-se, ao anoitecer, e que parece tornar-se, tal como Lisboa, o centro das atenções da comunidade inglesa.

Os visitantes observam Lisboa de vários locais, nomeadamente de Almada e do Tejo, durante momentos de lazer que fazem as personagens esquecer-se da doença de Lady Caroline até o narrador convocar, de novo, esse tema. Se Belmour seduz mulheres casadas, também Mrs. Derville, casada com o amado de Lady Caroline, pensa em seduzir Belmour, mas os "pre-occupied looks, distant civility, and decided melancholy" (103) do protagonista indicam-lhe que não teria tempo de o fazer em Lisboa. O narrador omnisciente adopta uma atitude algo cínica e denunciadora através de innuendos que sugerem ao leitor que a astuta Mrs. Derville decide, estrategicamente, trair o marido com um jovem português, obviamente da sua classe social: "and a genteel handsome young fidalgo, who, under the pretence of teaching 
her Portuguese, was become her constant attendant, and was received familiarly into her house; appeared much better suited to her purpose." (103) O narrador de Belmour denuncia assim a fachada da instituição do casamento, no qual ambos os cônjuges traem e fingem não ver o "desvio" (moral) do outro, que é, no fundo, a norma. Todas essas traições servem o propósito de denunciar a pseudo-felicidade e os casamentos arranjados e por interesse financeiro, encontrando marido e mulher formas, nem sempre ocultas, de se satisfazerem emocional e sexualmente. Essa hipocrisia é rejeitada pelo solitário protagonista, apaixonado por Emily, que, mais tarde, seduziria mesmo na companhia do seu marido, mas que, em Lisboa, é caracterizado e singularizado: "Belmour, to whom the whole of this society was insupportable, was grieved and mortified to see his sister thus forgetful of herself, as it appeared to him." (103) A autora parece sugerir, através da inconstância e dos erros das personagens, as vicissitudes da natureza humana. Após seis meses de permanência em Lisboa, Belmour, que tentava estar o menos possível com os ingleses, viaja até Espanha $\mathrm{e}$, várias vezes, até Sintra, onde arrenda uma pequena casa, "in one of the most beautiful situations of that romantic and singular place", (104) para se isolar durante dias e passear pelas paisagens marcadamente românticas de montes,

the craggy sides of which are partly covered with luxuriant evergreens, partly with majestic cork-trees, and varied in their fantastic forms - sometimes he would sit for hours pensively viewing the infinite beauty of the ocean in all its varied tints - then swiftly mount with agility of the very summit of the highest of the mountains, where still to be seen the picturesque ruins of a Moorish castle, the last refuge whence the gallant people were driven by victorious Spain. (104)

O espaço literário é assim simultaneamente símbolo de evasão pitoresca e de recolhimento interior, e a descrição da silhueta da paisagem natural de Sintra comunica intertextualmente com a da estrofe 19 de Childe Harold's Pilgrimage I (1812), de Byron: 
The horrid crags, by toppling convent crown'd,

The cork-trees hoar that clothe the shaggy steep,

The mountain-moss by scorching skies imbrown'd (Byron 30)

O narrador deixa claro que o imaginário de um Portugal muçulmano perdura no Castelo dos Mouros de Sintra. O elemento "mourisco" da paisagem e da cultura lusas fazia parte da poética da escrita de viagens britânica sobre Portugal e Espanha ${ }^{15}$ - como, aliás, revelam as associações aos antigos cavaleiros que Belmour partilha perante $\mathrm{o}$ castelo dos Mouros: "'Alas!' would he exclaim, 'why is chivalry no more - why are the genuine sentiments of the heart no longer ennobled by the imagination!'” (104) Aliás, o protagonista dialoga intertextualmente com Don Quixote, que busca, idealística e "alucinadamente", a sua Dulcineia del Toboso, quando afirma, no seguimento das palavras que acabámos de citar: "Have we gained by the change? By circumscribing them within the narrow limits of cold calculation?" (104) A associação de Portugal ao antigo universo da cavalaria, tal como a génese das relações anglo-portuguesas nesse tempo recuado, é feito, por exemplo, no "Advertisement" do poema Almada Hill, publicado em 1781, por W. J. Mickle, que funde a história de Portugal com a de Inglaterra através da ajuda dos cruzados anglo-normandos a D. Afonso Henriques quando da tomada de Lisboa aos "Mouros":

In the Twelfth Century, Lisbon, and great part of Portugal and Spain, were in possession of the Moors. Alphonso, the first King of Portugal, having gained several victories over that people, was laying siege to Lisbon, when Robert, Duke of Gloucester, on his way to the Holy Land, appeared upon the coast of that kingdom (...) Alphonso, among the rewards which he bestowed upon the English, granted to those who were wounded, or unable to proceed to Palestine, the Castle of Almada, and the adjoining lands. (Mickle: v)

15. Um estudo recente recorda: "the picturesque visions of nineteenth-century engravers, who depict an exotic and archaic Spain peopled by swart gypsies inhabiting Moorish ruins, Spain's beauties and vices alike are traced to Moorish influence. The origins of Spanish Romanesque sculpture, for instance, have been attributed to the effect of Moorish ivories, the lateness of the trains to an exotic strain in the Spanish character". (López-Portillo 51) 
A Sintra romântica permite a Belmour passeios solitários durante os quais reflecte sobre questões de cariz mais metafísico, por entre sinuosos vales, até que encontra uma igreja isolada. O leitor vai acompanhando o seu passeio no habitat ecológico dos montes da vila: "a green path, hedged closely on each side with lauristinus, myrtle, and Orange-tress, led to a small church, placed on an eminence, to which he ascended by several flights of steps". Dados factuais são estrategicamente apresentados como pensamentos do protagonista, permitindo este artifício literário caracterizá-lo como um explorador informado sobre as especificidades das ordens religiosas católicas:

on entering the door he judged it to belong to some convent of Capuchins, from the simplicity of its appearance, as the severity of their order admits of no gilding, no metal, no ornaments; and the plain ungaudy altar; with its row of wooden candlesticks, was here adorned only by a picture of Velasquez, which might indeed well have engaged the attention of the stranger ( ...) the church was ornamented and enlivened by flowers. (104-105)

O pitoresco espaço religioso é descrito como harmoniosamente invadido e embelezado pela natureza circundante, como se também a capela fizesse parte da natureza e os vasos de flores substituíssem os enumerados adornos artísticos habituais em templos religiosos: "stucco, marble, or gilding". (105) Nesse espaço espiritual que rejeita qualquer opulência e (consequentemente qualquer) distração exterior, Belmour descobre não estar sozinho, ao aperceber-se de um frade que, ajoelhado, reza com a cabeça sobre uma urna, que o narrador adjectiva de "monumental". (105) Tudo na capela é positivo, inclusive a aparência e a postura do frade que tem cerca de cinquenta anos e exibe "rather the marks of habitual melancholy than recente grief", (106) ou seja, o protagonista que não se identificava com a "sociedade" inglesa revê-se na figura do melancólico ermita, como se o laço da melancolia e do sofrimento os unisse. Apenas no volume terceiro do romance o leitor descobre, através de um aparte, que o frade se chama "don Juan de Colavrado (for that was the friar's name)." (287) Quando o frade entra no mosteiro, Belmour chora ao descobrir a razão pela qual 
a capela está repleta de flores: rodeiam a sepultura de Rosaura, cuja lápide "diz", em latim, "Rosaurae Sacer then followed 'posuit'". Este episódio sentimental(ista) não deixa dúvidas sobre a identificação do próprio jovem inglês (que efectua o seu Grand Tour marcado pela coita de amor) com Juan que cuida da sepultura e da memória da sua amada, como ele deveria fazer com a vida de Emily, que deixara em Inglaterra. A segunda vez que regressa a Sintra, Belmour cumprimenta o frade em latim, "Salve Nomine", (109) sendo, portanto, o latim associado ao universo católico português, como não poderia deixar de ser, até porque, como sabemos, na gruta do convento da Cortiça não ficcional encontra-se a sepultura de Frei Honório, com a inscrição em latim que Robert Southey transcreve, como veremos de seguida, $e$ que poderá ter influenciado esse detalhe do encontro dos dois enamorados de diferentes nacionalidades, que recorda que a experiência do amor é universal. Antes de a autora ficcionalizar Sintra, outros viajantes imortalizaram a beleza impressionante dessa serra, nomeadamente Robert Southey, que em Letters Written during a Short Residence in Spain and Portugal (509-511, 517-518), publicadas em 1797 (depois da visita de Damer a Portugal, mas antes da publicação de Belmour), e Damer ficcionaliza a paisagem da gruta e do templo sintrenses que Southey descreve, nomeadamente o "Cork Convent": 
We visited the Cork Convent: here I was shown a den in which a Hermit lived twelve years; a small hole for so large a vermin, but the virtue of burrowing there has procured him a place in Heaven, if we believe the inscription:

Hie Honorius,

vitam finivit,

Et ideo cum Deo

vitam revivit.

obit 1596. (Southey 517) ${ }^{16}$

O romance de viagem acaba por dialogar intertextualmente e ecoar os relatos de viagem sobre os espaços ficcionalizados de forma realista. No terceiro volume, na Turquia, Juan informa Belmour que, um ano depois da partida do jovem de Lisboa, como os religiosos não tinham dinheiro para recuperar o convento de Sintra, quase em ruínas, e após uma doença contagiosa ter matado vários frades, o convento foi encerrado e os frades mudaram-se para outro edifício. (288) A paisagem acústica dos monges a cantar em coro complementa a paisagem visual, e Belmour regressa à sua cottage com pena de ter que regressar a Lisboa, curioso para indagar mais sobre o frade e a sepultura, mas deve ir fazer companhia à irmã, por quem deixara todos os seus bens e deveres em Ingaterra. Aliás, a aprendizagem da liberdade e da entrega por amor é feita fora do Reino Unido, numa cultura e paisagem distantes, longe das amarras religiosas e sociais da Inglaterra em que Damer se sentia oprimida.

16. Robert Southey descreve os seus sentimentos em Sintra, semelhantes aos de Belmour: "I know not how to describe to you the strange beauties of Cintra; it is, perhaps, more beautiful than sublime, more grotesque than beautiful, yet I never beheld scenery more calculated to sill the beholder with admiration and delight. This immense rock or mountain is in part covered with scanty herbage, in parts it rises into conical hills, formed of such immense stones, and piled so strangely, that all the machinery of deluges and volcanoes must fail to satisfy the inquiry for their origin. Nearly at the base stands the town of Cintra and its palace; an old and irregular pile with two chimneys each shaped like a glass-house. But the abundance of wood forms the most striking feature in this retreat from the Portuguese summer. The houses of the English are seen scattered on the ascent half hid among cork trees, elms, oaks, hazels, walnuts, the tall canes, and the rich green of the lemon gardens (...). Had I been born at Cintra, methinks no inducement could have tempted me to leave its delightful springs and shades, and cross the dreary wilderness that insulates them. (...) I have now mentioned to you all that strangers usually visit at Cintra: but I cannot without a tedious minuteness describe the ever-varying prospects that the many eminences of this wild rock present, or the little green lanes over whose bordering lemon gardens the evening wind blows so cool, so rich! (...) I am informed that Cintra has been celebrated in song, by Captain Jeremiah Thompson, of the Polly Schooner". (509-511, 517-518) 
Por sugestão de Mrs. Marsden e do casal Derville, fartos de estar em Lisboa, a viagem de Lady Caroline ao Sul da Europa estende-se por Espanha e Itália, na companhia desses amigos, de empregados e de um médico que viajara com eles para cuidar de Caroline. A partida acontece rapidamente, Belmour acompanha irmã até à Aldeia Galega, e, estando totalmente sozinho e livre de deveres familiares, decide voltar a Sintra antes de regressar a Inglaterra. Na capela, Belmour ouve missa, elemento da soundscape lusa, antes de passear e dialogar em português com don Juan de Colavrado, pois a estada permitira-lhe aprender a língua portuguesa, tal como a própria Anne Damer afirma que fizera facilmente, (Lewis 1, 273) como referimos na primeira parte. O frade acaba também por se identificar com a melancolia que caracteriza o protagonista, convidando-o a descansar e a comer na sua húmida e austera cela. $\mathrm{O}$ mosteiro encontra-se rodeado por ruínas de um templo pagão e o seu interior gótico é adornado por uma fonte e exóticas árvores de fruto (para o leitor britânico), nomeadamente limoeiros e laranjeiras. Dias depois, Belmour parte para Inglaterra, como informa o capítulo 11, e através da elipse e do sumário o protagonista chega a Falmouth, após doze dias de viagem. Mais tarde (308) também a sua irmã regressa a casa, via Lisboa. Percorrendo posteriormente a Europa, o jovem inglês volta a encontrar o choroso, amigável, ex-supersticioso (291) e generoso "friar of Cintra" (287) na Turquia, antes de regressar mais uma vez a Inglaterra, e decide, após falar de novo com ele, reconquistar Emily.

Num romance sobre namoros e casamentos infelizes, melancolia byroniana, frustração e realização pessoal, (Schmid 37-38) e através do qual Anne critica o etnocentrismo inglês, (Gross, A Life 340) Portugal assume-se como o espaço pitoresco (de paisagens góticas e mouriscas) de aprendizagem do amor devoto, através do sentimental(ista) exemplo do frade ibérico. Tendo cortejado Lady Roseberg em vão, pois ela engana-o com outro amante, St. Fort, Belmour acompanha a sua irmã, Caroline, que também foi rejeitada, a Portugal. No entanto, o protagonista, receptivo à aprendizagem e à mudança, regressa a Inglaterra para conquistar Emily, pois concluíra que sempre a amara. Se muitos casamentos no romance são infelizes (Mr. 
Rycot, Mrs. Stainville, pais de Emily), Belmour tem um fim feliz, pois Courtenay morre a tempo de Emily e o protagonista casarem harmoniosamente.

A primeira parte deste estudo permitiu-nos acompanhar a viagem da escultora Anne Damer a Lisboa, por motivos de doença, entre 1790 e 1791, bem como os elementos culturais, as práticas sociais e os espaços comentados nas missivas que envia aos amigos. Na segunda parte analisámos a forma como a autora ficcionalizou essas paisagens e comportamentos no segundo volume de Belmour, sobretudo no capítulo décimo, em que Lisboa funciona como espaço de convalescença para Lady Caroline, e Sintra permite evasão/aprendizagem a Belmour. O romance sentimental de viagem em questão ecoa a forma como, sobretudo após o Iluminismo, a escrita de viagens se torna um processo de compreensão intercultural, quer para perpetuar, quer para desconstruir e reescrever estereótipos e imagens ora positivas, ora negativas. Essa mesma atitude é mimetizada em narrativas ficcionais escritas por viajantes, como é o caso de Belmour, que Damer começa a redigir na capital lusa. Como é sabido, (d)escrever o Outro implica o confronto com a identidade do Self, e, no estrangeiro, ou já de volta a "casa", a viajante-escritora narra-se a si e às suas ansiedades, expectativas, interesses ocultos e limitações sobretudo nas entrelinhas da descrição do Outro, muitas vezes representado (e procurado) como "pitoresco" ou diferente do Self. E a autora, através do narrador, narra-transfigura também as suas experiências, as pretéritas e as presentes, e também as suas transgressões, limitações, digressões físicas, mentais e escritas, os seus géneros (gender e genre), nível de literacia e de conhecimentos sobre o que observa, a sua classe social, a sua etnia e a sua nação (ou parte dela). Portugal é, assim, um espaço católico de superstição, evasão e de aprendizagem para Belmour, um espaço quer histórico multidimensional porque gótico e mourisco, quer católico e pitoresco, onde o protagonista pode isolar-se da comunidade inglesa, e, confrontado com o exemplum do frade ibérico, reflectir sobre a vida e os sentimentos que nutre por Emily, que deixara em Londres, onde regressa após a aprendizagem que a longa e fragmentada viagem lhe proporciona. 


\section{Obras Citadas}

"Art 21. Belmour. 12 mo. 3 vols. 10s. 6d Boards. Johnson." The Monthly Review 38 (Julho 1802): 314.

Begg, Tom. "Damer, Anne Seymour, n. Conway." Biographical Dictionary of Scottish Women. Ed. Elizabeth Ewan, Sue Innes, Siân Reynolds e Rose Pipes. Edimburgo: Edinburgh U P, 2006. 91.

Benforado, Susan, "Anne Seymour Damer (1748-1828). Sculptor." Tese de Doutoramento. University of New Mexico, 1986.

Bettany, Lewis. (ed.) Edward Jerningham and his Friends: A Series of Eighteenth Century Letters. New York: Brentano's, 1919.

Black, Jeremy. The British Abroad: The Grand Tour in the Eighteenth Century. Stroud: The History Press, 2011.

Byron, Lord. The Major Works, Col. "Oxford World Classics". Ed. Jerome J. McGann. Oxford: Oxford U P, 2008.

Cardinal, Roger. "Romantic Travel." Rewriting the Self: Histories from the Renaissance to the Present. Ed. Roy Porter. Londres: Routledge, 1997. 135-155.

Damer, Anne Seymour, Belmour: A Modern Edition. Ed. Jonathan David Gross. Evanston: Northwestern U P, 2011.

Elfenbein, Andrew. Romantic Genius: The Prehistory of a Homosexual Role. New York: Columbia U P, 1999.

Frawley, Maria H. Invalidism and Identity in Nineteenth-Century Britain. Chicago: U of Chicago P, 2004.

Gifra-Adroher, Pere. Between History and Romance: Travel Writing on Spain in the Early Nineteenth Century. Madison: Fairleigh Dickinson U P, 2000.

Godwin, William. Memoirs of the Author of A Vindication of the Rights of Woman. Ed. Pamela Clemit e Gina Luria Walker. Peterborough: Broadview Press, 2001.

Grabham, Michael C. The Climate and Resources of Madeira as Regarding Chiefly the Necessities of Consumption and the Welfare of Invalids. Londres: John Churchill \& Sons, 1870.

Gross, Jonathan David. "Time Line." Anne Seymour Damer. Belmour: A Modern Edition. Ed. Jonathan David Gross. Evanston: Northwestern U P, 2011. xv-xvi. 
---. "Biographical Note." Anne Seymour Damer. Belmour: A Modern Edition. Ed. Jonathan David Gross. Evanston: Northwestern U P, 2011. ix-xiv.

---. "Introduction." Anne Seymour Damer. Belmour: A Modern Edition. Ed. Jonathan David Gross. Evanston: Northwestern U P, 2011. xvii-l.

---. "Childish Ways: Anne Damer and Other Percursors to Childe Harold's Pilgrimage." Byron and Latin Culture: Selected Proceedings of the 37th International Byron Society Conference. Ed. Peter Cochran. Newcastle upon Tyne: Cambridge Scholars Publishing, 2013. 181-197.

---. The Life of Anne Damer: Portrait of a Regency Artist. Lanham: Lexington Books, 2014.

Hickey, William. Memoirs of William Hickey II (1775-1782). Ed. Alfred Spencer. Londres: Hurst \& Blackett, 1925.

Lewis, Lady Theresa (ed.) Extracts of the Journals and Correspondence of Miss Berry from the Year 1783 to 1852. 1. Londres: Longmans, Green, 1865.

The Lisbon Guide Containing Directions to Invalids who Visit Lisbon. Londres: J. Johnson, 1800.

López-Portillo, José-Juan. Spain, Portugal and the Atlantic Frontier of Medieval Europe (The Expansion of Latin Europe, 1000-1500). Londres: Routledge, 2013. Melville, Lewis (ed.) The Berry Papers: Being the Correspondence Hithertho Unpublished of Mary and Agnes Berry (1763-1852). Londres: John Lane, 1914.

Mickle, William Julius. Almada Hill: An Epistle from Lisbon. Oxford: W. Jackson, 1781.

Noble, Percy. Anne Seymour Damer: A Woman of Art and Fashion, 1748-1828. Londres: Kegan Paul, 1908.

Parker, Andrew Mary Russo et al. (ed.) Nationalism and Sexualities. New York: Routledge, 1982.

Pemble, John. The Mediterranean Passion: Victorians and Edwardians in the South. Oxford: Clarendon Press, 1987.

Puga, Rogério Miguel. “Ficcionalizar Lisboa como 'Colónia' Britânica de Convalescença: A Estética do Sofrimento Feminino em Mary, A Fiction (1788), de Mary Wollstonecraft". Ed. Gabriela Gândara Terenas. Revista de Estudos Anglo-Portugueses/Journal of Anglo-Portuguese Studies 25 (2016): 43-77.

Shand, Alexander. "The Pleasures of Sickness." Blackwood's Edinburgh Magazine 145 (Abril 1889): 546. 
Shell, Alison. Catholicism, Controversy and the English Literary Imagination, 15581660. Cambridge: Cambridge UP, 2006.

Yarrington, Alison. "The Female Pygmalion: Anne Seymour Damer, Allan Cunningham, and the Writing of a Woman's Sculptor's Life." The Sculpture Journal 5:1 (1997): 32-44.

Schmid, Susanne. British Literary Salons of the Late Eighteenth and Early Nineteenth Centuries. New York: Palgrave Macmillan, 2013.

Southey, Robert. Letters Written during a Short Residence in Spain and Portugal. Londres: Bulgin and Rosser, 1797.

Todorov, Tzvetan. "The Journey and its Narratives." Transports: Travel, Pleasure, and Imaginative Geography, 1600-1830. Ed. Chloe Chard e Helen Langd. Trans. Alyson Waters. New Haven: Yale U P, 1996. 287-96.

Walpole, Horace. Letters of Horace Walpole, Earl of Oxford, to Sir Horace Mann, British Envoy at the Court of Tuscanny 2. New York: George Dearborn, 1833.

Wollstonecraft, Mary. Mary, A Fiction and The Wrongs of Woman, or Maria. Ed. Michelle Faubert. Londres: Broadview Editions, 2012. 